\title{
Development of Student Worksheet with Guided Inquiry to Train High Order Thinking Skills on the Reaction Rate Materials
}

\author{
Fairuziyah Aizzatun Nisa, *Harun Nasrudin \\ Chemistry Department, Faculty of Mathematics and Natural Sciences, Universitas Negeri \\ Surabaya, Ketintang Campus, Surabaya, 60231, Indonesia \\ *Corresponding Author e-mail: harunnasrudin@unesa.ac.id
}

Received: January 2022; Revised: January 2022; Published: January 2022

\begin{abstract}
This study aimed to know the feasibility of the students' worksheets with guided inquiry to train high-order thinking skills on the reaction rate materials. The research method used is Research and Development by Borg \& Gall until the limited trial stage. The limited trial was conducted on 33 students in class XI IPA 1 SMAN 1 Gedangan Sidoarjo. The student worksheets with guided inquiry are feasible based on validity, practicality, and effectiveness aspects. Aspects of validity include content validity and construct validity indicate that the student worksheet developed is very valid with a percentage of $93 \%$ and $89.70 \%$ for each criterion. Practicality observed from the results of the student response questionnaires gets a percentage of $94-100 \%$ with a very practice category and supported by more relevant student activities than irrelevant activities. The effectiveness is seen from the results of the knowledge domain test and HOTS with Paired Sample T-Test each getting a Sig. (2tailed) of 0.000 which means the difference in the average value between before and before the student worksheet was given. In addition, the effectiveness is also viewed from the $\mathrm{n}$-gain. The $\mathrm{n}$-gain results on the knowledge domain test showed $84.84 \%$ of students with high category and $15.16 \%$ of students with medium category, and the n-gain results on the HOTS test showed $93.93 \%$ of students with high category and $6.07 \%$ of students with medium category. So, it can be stated that the student worksheet with guided inquiry is declared feasible and can train students' HOTS.
\end{abstract}

Keywords: Student Worksheet, Guided Inquiry, High Order Thinking Skills, Reaction Rates

How to Cite: Nisa, F., \& Nasrudin, H. (2022). Development of Student Worksheet with Guided Inquiry to Train High Order Thinking Skills on the Reaction Rate Materials. Prisma Sains : Jurnal Pengkajian Ilmu dan Pembelajaran Matematika dan IPA IKIP Mataram, 10(1), 69-83. doi:https://doi.org/10.33394/j-ps.v10i1.4780

https://doi.org/10.33394/j-ps.v10i1.4780

Copyright $\odot$ 2022, Nisa \& Nasrudin This is an open-access article under the CC-BY License.

\section{INTRODUCTION}

The curriculum is an educational element as a guide for the implementation of studying. The 2013 curriculum was developed to improve the previous curriculum (Purwanto, 2013). The 2013 curriculum is designed so that students are more active in seeking, processing, and constructing knowledge in the learning process (Permendikbud, 2013).

Based on the 2013 curriculum, one of the subjects specializing in Mathematics and Science is chemistry. The connection of studying chemistry is understanding the phenomena of everyday life. In chemistry learning, students are trained to carry out the process of scientific discovery as a scientific approach (Cahyani et al., 2019). Permendikbud No. 37 (2018) states that one of the chemicals that requires proof through experiments is the reaction rate (Permendikbud, 2018).

The rate of reaction is a chemistry subject matter that has the characteristics of requiring proof through experiments (Damaianti et al., 2019). One of the materials that need proof is the sub-material factors that affect reaction rates. It is supported by KD 3.6 
Explaining the factors that affect the rate of a reaction using collision theory, and KD 4.7 Designing, conducting, concluding, and presenting experimental results on factors that affect the reaction rate and reaction order (Permendikbud, 2018). Based on this, students need to be trained in High Order Thinking Skills (HOTS) in proving through experiments to develop the concepts learned and apply them in everyday life to the factors that affect reaction rates (Nurkholik \& Yonata, 2020). The teacher trains HOTS skills to students as a mandate from the 2013 curriculum so that students can overcome the problems they have (Brookhart, 2010).

HOTS describes the type of learning that requires cognitive processing. HOTS can be useful so that students' abilities are honed to solve problems, conceive and construe chemical concepts (Irham et al., 2017). According to Bloom's Taxonomy, skills are divided into 2, namely Low Order Thinking Skills (LOTS) and HOTS contained Bloom's taxonomy. Bloom's taxonomy includes the HOTS category, namely analyzing (C4), evaluating (C5), and creating (C6) (Brookhart, 2010).

In practicing HOTS skills, teachers need teaching materials that facilitate learning activities. Student worksheets are teaching materials in the learning process that can make the interaction between students and teachers more effective to increase student learning activities and achievements (Andriani \& Yonata, 2018). The use of the student worksheet was developed by the constructivist theory in which students play an active role. But so far, the Student Worksheets used in learning have not been maximized in training HOTS to students (Abizar, 2017).

Based on the results of the pre-research on students of class XI IPA 1 SMAN 1 Gedangan Sidoarjo showed that 33 respondents obtained a result of $84.84 \%$ stating that the material for the rate of reaction is difficult. Based on the HOTS ability, as many as $87.87 \%$ of students stated that they had never practiced analyzing a phenomenon, $90.90 \%$ had never done practical activities, and $93.93 \%$ had never practiced designing on their own an experimental flow. In the current use of student worksheets, as many as $88.23 \%$ of students stated that they had not trained their HOTS. So, $93.93 \%$ of students agree if a student worksheet is developed to train HOTS on the reaction rate material.

The outcomes of interviews with chemistry teachers at SMAN 1 Gedangan Sidoarjo found that teachers still apply teacher-centered learning where students are still passive, and there is no practicum in learning activities, resulting in a lack of HOTS training for students.

The results of developing HOTS-based worksheets have been carried out by several researchers and show a positive effect. Research conducted by Aditya (2020) shows that HOTS-based worksheets can train HOTS and students' thinking skills. In addition, Anjelicha's research (2020) shows that HOTS-based worksheets are effective in training students' HOTS. The HOTS aspects in the student worksheets that are trained include the ability to analyze $\mathrm{C} 4$ including formulating problem formulations, determining experimental variables, and analyzing experimental data; the ability to evaluate C5 includes identifying problems, designing experimental procedures, and making conclusions; the ability to create C6 includes formulating hypotheses and creating ideas (Nurkholik \& Yonata, 2020).

Efforts that can be made to train HOTS with the help of student worksheets are to apply a learning model that can train high-level thinking and motivate students. The learning model that can be a solution to train HOTS on the factors that affect the rate of reaction is guided inquiry (Khaleel Younis, 2017). The main character of the inquiry model is that student activities are required to seek and find concepts with critical and analytical thinking (Firdausichuuriyah \& Nasrudin, 2017).

At the guided inquiry stage, students are required to solve problems in search of investigative knowledge or the discovery of scientific concepts by developing a scientific way of thinking (Mulyana, S., Rusdi, \& Vivanti, 2018). In the inquiry strategy, students are 
expected to get the concepts from the material by reasoning logically and critically to clarify a problem or explore the realm of science (Imama \& Nasrudin, 2015).

The results of research conducted by Anjelicha (2020), the feasibility test for the development of the Student Worksheet used in training HOTS is a student worksheet based on group investigation. Validity is reviewed based on content and construct with percentage each criterion are $88.7 \%$ and $90.9 \%$. Practicality based on student responses shows of percentage $86.2-100 \%$ with very practice category. The effectiveness in terms of the n-gain results of students who got the medium category was $6 \%$ and the high category was $94 \%$ (Anjelicha \& Ismono, 2020).

Based on the problems, it is necessary to develop effective and innovative teaching materials in learning activities in the form of student worksheets with guided inquiry to train students' HOTS. Therefore, the researcher aims to conduct a feasibility study on the development of a student worksheet with guided inquiry to train HOTS on the reaction rate materials.

\section{METHOD}

The research method used is a development by Borg \& Cell, namely Research and Development (Sugiyono, 2015). The development steps according to Research and Development include the preliminary stage, namely potential and problems, and data collection; the development study stage, namely product design, product design review, product design revision, product design validation, and limited trial; the evaluation stage is the revision of product design and mass production (Gustiani, 2019). The stages of the Research and Development method are shown in Figure 1.

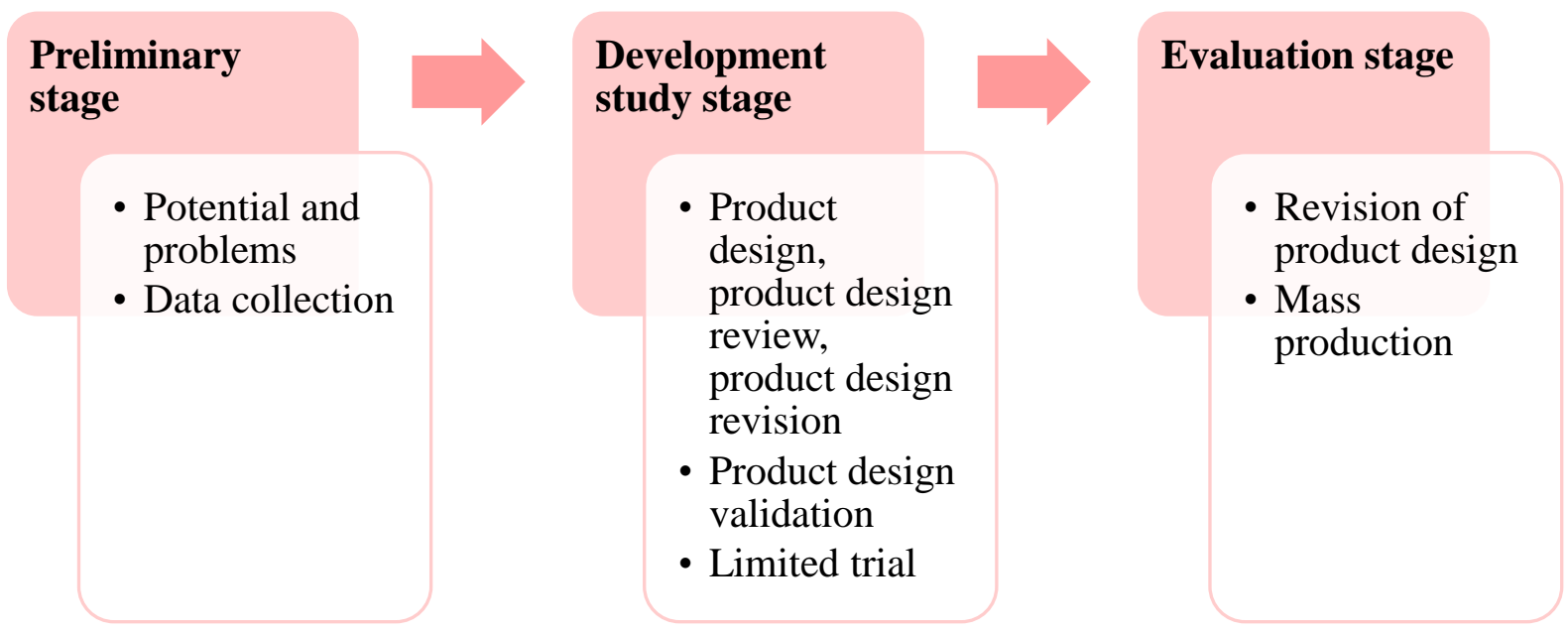

Figure 1. The Stages of Research and Development Method

This research is only limited to a limited trial on development studies. The data source comes from the results of the validation and limited trial data that was carried out in class XI IPA 1 SMAN 1 Gedangan Sidoarjo with 33 students with heterogeneous abilities and formed groups. The instruments used were validation sheets, student response questionnaires, student activity observation sheets, pretest-posttest knowledge domains, and HOTS.

The data from the results of the study were analyzed descriptively qualitatively with input in the form of criticism and suggestions by the chemistry lecturer on the developed student worksheets. Criticisms and suggestions are used to improve the draft of the developed student worksheets. Meanwhile, the data from the validation results were analyzed on every aspect (point) that existed in each of the assessed eligibility criteria. The category is reviewed 
of content, graphic, linguistic, presentation, and suitability of knowledge domain and HOTS. Assessment indicators based on a Likert scale are presented in Table 1.

Table 1. Score Category Assessment Validation Sheet

\begin{tabular}{cc}
\hline Score & Category \\
\hline 1 & Not suitable \\
2 & Less suitable \\
3 & Quite suitable \\
4 & Suitable \\
5 & Very suitable \\
\hline
\end{tabular}

(Riduwan, 2015)

The validity results were analyzed to determine the percentage of each criterion by using the formula:

Description:

$$
\mathrm{P}(\%)=\frac{\sum \text { score obtained }}{\sum \text { score criteria }} \times 100 \%
$$

Score criteria $=$ highest score $\times$ number of points $\times$ total of respondents

Then the presentation of the results is interpreted in Table 2.

(Suyono \& Hariyanto, 2015)

Table 2. Interpretation of Validity Category

\begin{tabular}{cc}
\hline Percentage $(\%)$ & Category \\
\hline $0-20$ & Not valid \\
$21-40$ & Less valid \\
$41-60$ & Quite valid \\
$61-80$ & Valid \\
$81-100$ & Very valid \\
\hline
\end{tabular}

(Riduwan, 2015)

A student worksheet is considered to meet the category if each component gets a percentage value of $\geq 61 \%$ with a valid and very valid category so that it is feasible to use.

Response questionnaires distributed after a limited trial were used to demonstrate the practicality of the worksheets. Analysis of student response questionnaires by changing the frequency value into a percentage using the formula:

Description:

$$
\mathrm{P}(\%)=\frac{F}{N} \times 100 \%
$$

$\mathrm{P}=$ response percentage

$\mathrm{F}=$ number of students who responded positively

$\mathrm{N}=$ number of respondents

(Riduwan, 2015)

The results obtained will be analyzed based on the questionnaire response assessment category presented in Table 3.

Table 3. Student Worksheet Assessment Category from Student Questionnaire Results

\begin{tabular}{cc}
\hline Percentage $(\boldsymbol{\%})$ & Category \\
\hline $0-20$ & Very impractical \\
$21-40$ & Not practical \\
$41-60$ & Practical enough \\
$61-80$ & Practical \\
$81-100$ & Very practical \\
\hline
\end{tabular}

(Riduwan, 2015)

Based on the category in Table 3, if the percentage of student responses is $\geq 61 \%$, then the student worksheet can be said to be practical and very practical. The practicality of the 
student worksheet is also supported by the activities of students when using the developed student worksheet if the percentage of relevant activities is greater than the irrelevant activities (Julistiawati \& Yonata, 2013). Student activity is calculated using the formula:

$$
\text { Activity Precentage }(\%)=\frac{\sum \text { frequency of activity that appears }}{\sum \text { frequency of overall activity }} \times 100 \%
$$

(Arifin, 2009)

Data analysis of the knowledge domain and HOTS of students to find out whether the knowledge domain and HOTS have been trained or not. This analysis can also find out the realm of knowledge and HOTS of students before and after using the student worksheet. The increase in the domain of knowledge and HOTS of students seen from the results of the pretest and posttest can be calculated using the formula:

$$
\text { Score }=\frac{\sum \text { score obtained }}{\sum \text { score maximal }} \times 100 \%
$$

Then it was analyzed whether there were differences in the domain of knowledge and HOTS between before and after being given student worksheets using the Paired Sample T-Test. The basis for decision making from the Paired Sample T-Test is seen from the value of Sig. (2-tailed). If Sig. (2-tailed) $<0.05$ then there is a significant difference in the results of the knowledge domain test and the HOTS test between before and after using the student worksheets, if Sig. (2-tailed) $>0.05$ then there is no significant difference in the results of the knowledge domain test and the HOTS test between before and after using the student worksheets (Tarumasely, 2020). Meanwhile, to determine the increase in knowledge domain tests and HOTS tests, the n-gain score is calculated using the formula:

$$
\mathrm{N}-\text { Gain }=\frac{\text { posttest score-pretest score }}{100-\text { pretest score }}
$$

(Hake, 1998)

The assessment category for the Domain of Knowledge test and HOTS test are in Table 4.

Table 4. N-Gain Score Level Category

\begin{tabular}{|c|c|}
\hline Score & Category \\
\hline $\mathrm{g} \geq 0.7$ & High \\
\hline $0.3 \leq \mathrm{g} \geq 0.7$ & Medium \\
\hline $\mathrm{g}<0.3$ & Low \\
\hline
\end{tabular}

(Hake, 1998)

The use of a developed student worksheet is stated to be effective in training the domain of knowledge and HOTS if the category for assessing the domain of knowledge and HOTS of students with $\mathrm{N}$-Gain scores are included in the high and medium categories.

\section{RESULTS AND DISCUSSIONS}

The results of this research are the results of the student worksheet development stage, the validity of the student worksheet, student activities, student responses, knowledge domain tests, and HOTS tests.

The first stage is based on the $R \& D$ development method, before conducting a development study, a preliminary study is carried out. Where this preliminary study is in the form of field studies and literature studies. At this stage, a preliminary study was conducted to find out the problems categoriesntials of class XI science students at SMAN 1 Gedangan Sidoarjo covering the conditions of students, teachers, and the school environment. This was done through pre-research questionnaires and interviews with chemistry teachers. The results of the analysis require the existence of student worksheets with guided inquiry to train HOTS on the reaction rate materials. 
The second stage is a development study which includes (1) product design, product design review, product design revision (2) product design validation and limited trial.

\section{Product Design Stage}

At the design stage, student worksheets are stored in draft form. The contents of the student worksheet that must be considered are core and basic competencies, indicators, learning objectives, instructions, concept maps, and activities that include guided inquiry stages. According to Arends, there are 6 stages of learning with the guided inquiry model, namely:

1. Focusing and explaining the inquiry process

Activities in phase 1 include focusing and explaining the inquiry process. In this phase, the teacher begins the lesson by appreciating the material at the previous meeting. In addition, the teacher also motivates students and conveys the objectives of learning (Arends, 2012).

2. Presenting problems or phenomena

The activities in phase 2 are presenting inquiry problems. In this phase students are divided into several heterogeneous groups and then given time to read the phenomena that exist on the student worksheets. In the student worksheets, there are phenomena in everyday life and phenomena in the laboratory that will be investigated through experimental activities (Arends, 2012).

3. Formulate hypotheses to explain the problem of a phenomenon

Activities in phase 3 are formulating hypotheses to explain the problem. In this phase, students will be guided by the teacher to work on student worksheets so that students' HOTS are trained, first identifying problems based on phenomena (cognitive level C5), then identifying experimental variables (cognitive level C4). After finding the keywords in the form of variables, students will be guided by the teacher to formulate problems (cognitive level $\mathrm{C} 4$ ), then students read the literature in chemistry textbooks so that the hypotheses formulated have a basis (Arends, 2012).

4. Collecting data to test hypotheses

Activities in phase 4 include collecting data to test hypotheses by designing experimental procedures, identifying tools and materials and collecting data by conducting experiments (Arends, 2012).

5. Formulate an explanation or conclusion

Activities in phase 5 students are asked to formulate explanations or conclusions by analyzing experimental data and then making conclusions based on the analysis and experimental results (Arends, 2012).

6. Reflect on problems and thought processes

Activities in phase 6 include reflection on problems and thought processes by working on application questions, so students can recall how to solve problems that have been given and present other examples in everyday life (Arends, 2012).

Learning activities with the guided inquiry model require an investigation to find their own answers, so that experiments are raised that serve to strengthen the concepts and attitudes of HOTS-oriented analysis. In inquiry learning, students are expected to be able to practice HOTS including analyzing, evaluating, and creating (Khafida \& Ismono, 2021). 


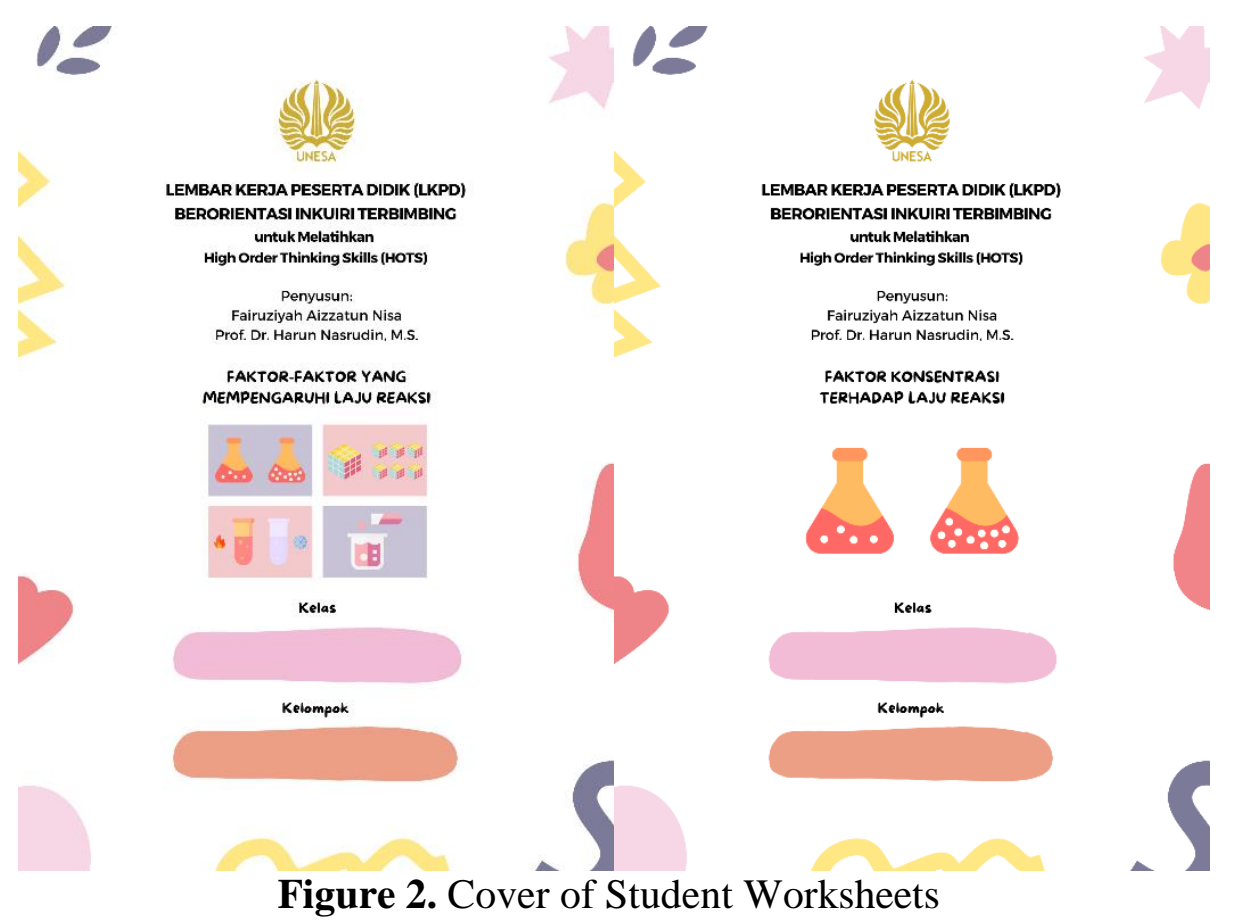

The main cover of student worksheet contains 4 images that represent 4 reaction rate factors, namely 1) concentration is described through two solutions that have different concentrations indicated by differences in the number of particles; 2) the surface area is described by the difference in the surface area of the touch plan; 3) the temperature is described through high and low-temperature solutions; 4) the catalyst is described by the addition of a catalytic agent in a chemical reaction.

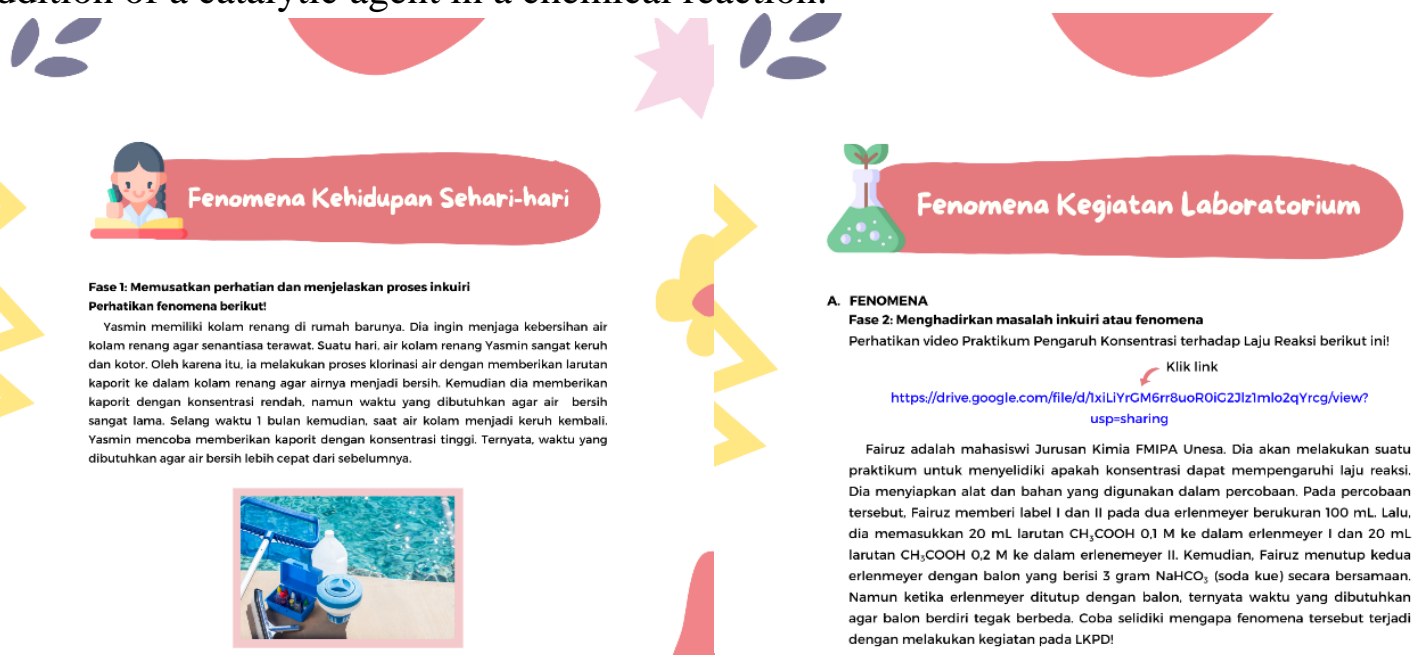

Figure 3. Guided Inquiry Stage in Student Worksheet

Figures 2 and 3 are fragments of the prototype made at the student worksheet design stage according to the results of the analysis that has been done previously. After the student worksheets are designed, then they are reviewed by chemistry lecturers to be given suggestions and comments to improve the student worksheets. The results of the revised study and the revised results will be validated.

\section{Product Design Validation Stage}

The results of the revised student worksheet were validated by 2 chemistry lecturers of Unesa and 1 chemistry teacher of SMAN 1 Gedangan Sidoarjo to produce a student 
worksheet worthy of a trial. The validation category follows the validity category by Nieveen that includes content validity and construct validity.

Content validation is seen based on its relevance to the content and learning objectives. The results of the data analysis can be seen in Figure 4.

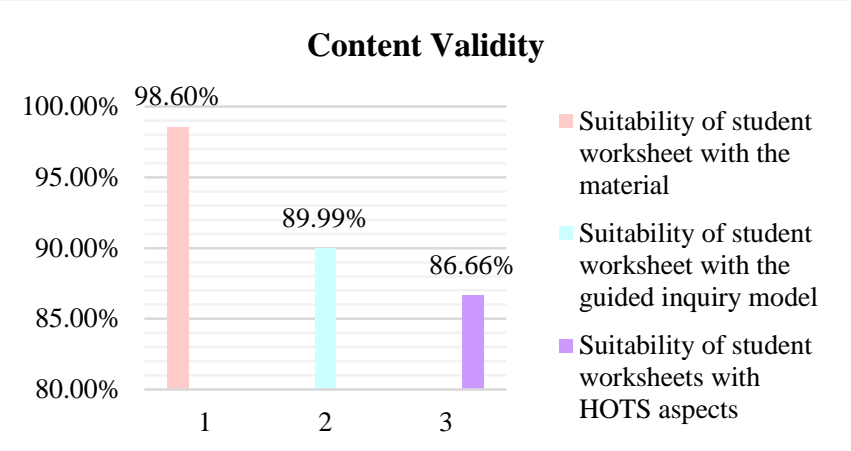

Figure 4. Student Worksheet Content Validation Results

Based on the results of the following validity analysis, the suitability of the student worksheet with the material has 5 aspects, namely material according to the revised 2013 curriculum, indicators according to competence, material according to objectives, and material aspects according to basic competencies, has a validity of $100 \%$ with very valid category. While the questions according to the indicators are $93 \%$ with very valid category.

The suitability of the student worksheet with the guided inquiry model has 6 aspects including aspects of focusing attention and explaining the inquiry process having validity of $83.33 \%$ with very valid category, aspects of presenting inquiry problems or phenomena having validity of $93.33 \%$ with very valid category, aspects of formulating hypotheses to explain the problem of a phenomenon has a validity of $86.67 \%$ with very valid category, the aspect of collecting data to test the hypothesis has a validity of $93.33 \%$ with very valid category, the aspect of formulating an explanation or conclusion has a validity of $83.33 \%$ with very valid category, and aspects reflecting problems and thought processes have a validity of $90 \%$ with very valid category.

The suitability of the student worksheet with the HOTS aspect being trained contains C4 analyzing which has a validity of $93.33 \%$ with very valid category, C5 evaluating has a validity of $86.67 \%$ with very valid category and C6 creating has a validity of $80 \%$ with valid category.

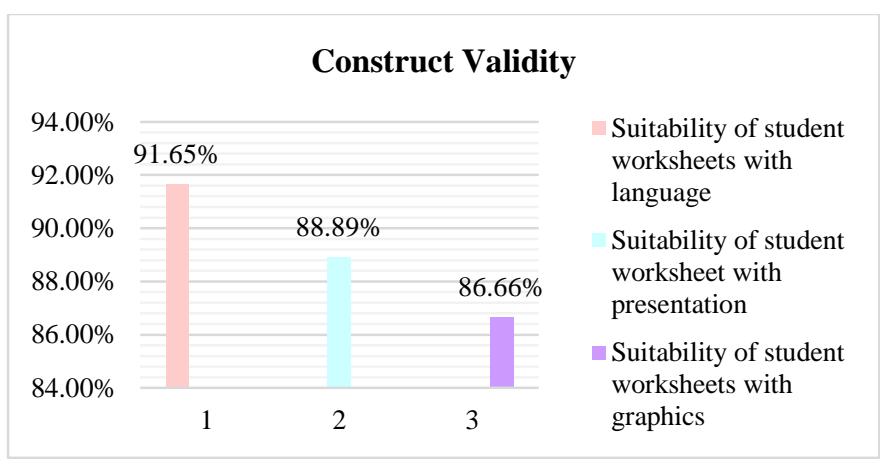

Figure 5. Student Worksheet Construct Validation Results

The suitability of the student worksheet with the language has 4 aspects, namely the use of nice and accurate language by $93.33 \%$, the use of clear or easy-to-understand language by $93.33 \%$, the sentences used do not contain double meanings by $93.33 \%$, and the presentation of logical and systematic concepts by $86.67 \%$. It shows the suitability of the student worksheet with the language has a very valid category. 
The suitability of the student worksheet with the presentation has 3 aspects, namely the cover presenting the contents of the student worksheet has a validity of $86.67 \%$, the availability of a place to write the answers as needed is $86.67 \%$, and the comprehensiveness of the components in the student worksheet for each of these aspects is $93.33 \%$. It shows the suitability of the student worksheet with the presentation has a very valid category.

The suitability of the student worksheet with graphics has 5 aspects including illustration images according to the content has a validity of $86.67 \%$ with very valid category, the use of fonts makes it easier to read student worksheet by $93.33 \%$ with very valid category, attractive cover design by $80 \%$ with valid category, as well as the layout of text, images, and matching tables have a validity of $93.33 \%$ with very valid category.

Based on the results of the data analysis of content validation and construct validation, the total percentages were $93 \%$ and $89.70 \%$, respectively. So that the student worksheet is stated to be very valid because it meets the student worksheet category if for each component it gets a percentage value of $\geq 61 \%$ and is suitable for use in learning.

\section{Limited Trial Stage}

Student worksheets that have gone through the validation stage and are declared eligible will be tested. The limited trial was carried out on January 10 and 12, 2022 with total use of 8 lesson hours for 4 student worksheets tested on 33 students of XI IPA 1 SMAN 1 Gedangan Sidoarjo. Learning activities were divided into two meetings, where the first meeting discussed the concentration and surface area factors. While the second meeting discussed the temperature factor and the catalyst factor.

The following is the student worksheet product in a limited trial using the Guided Inquiry model.

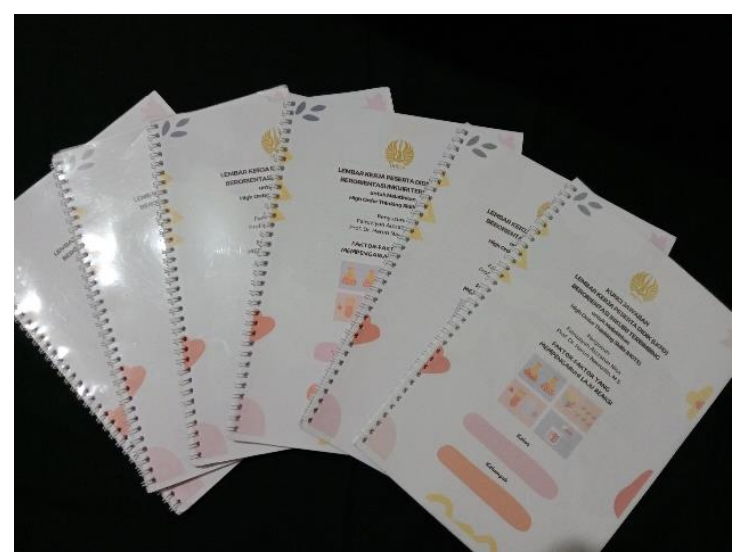

Figure 6. Student Worksheet Product

The following is the documentation of the use of student worksheets in a limited trial at SMAN 1 Gedangan Sidoarjo.

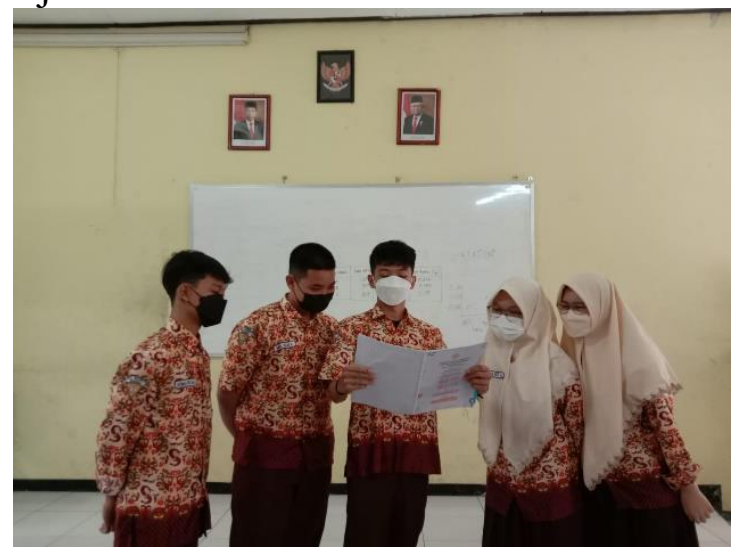

Figure 7. The Activity of Communicating Experimental Results 


\section{Practicality}

Practicality in student worksheets is reviewed from the response questionnaire. Student responses are responses after using student worksheets. The response data is supported by relevant student activities. Practicality purpose to find out if student worksheets can be applied in real-life learning activities with a guided inquiry stage.

\section{Student Activities}

Activities were assessed by 3 observers referring to the execution of the guided inquiry stage. Guided Inquiry learning is applied by forming small groups with heterogeneous abilities to study together and find concepts.

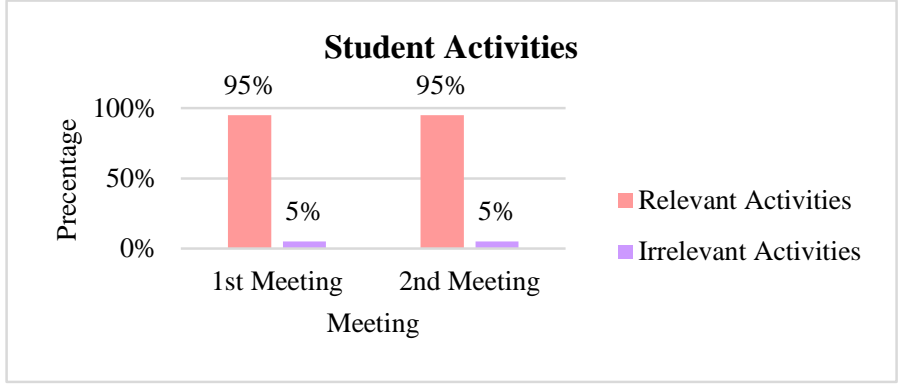

Figure 8. Student Activities

Based on Figure 7. Relevant activities during learning activities are greater than irrelevant activities. The relevant percentages of student activities consist of answering questions from the teacher, expressing opinions, reading phenomena in the student worksheet, conducting group discussions, identifying problems, determining experimental variables, formulating problem formulations, formulating hypotheses, designing experimental procedures, collecting data (conducting experiments), recording experimental results, analyzing experimental data, making conclusions, communicating experimental results, and reflecting on problem situations and thinking processes by working on student worksheet questions. While irrelevant activities such as being busy during experimental activities, playing cellphones, and doing other activities that interfere with learning activities.

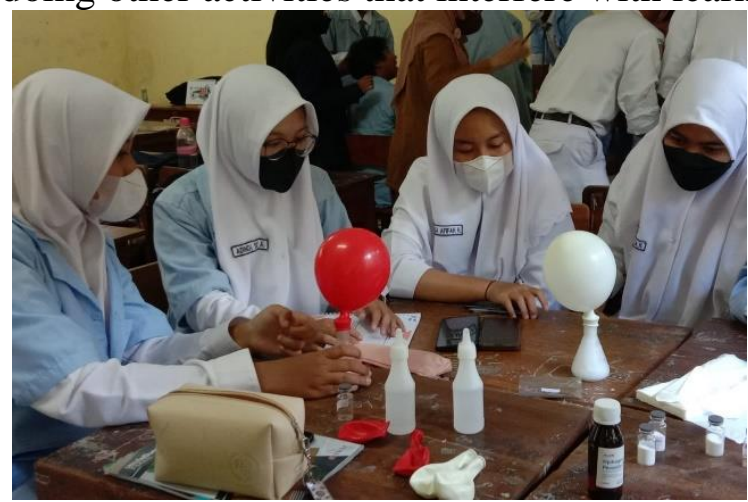

Figure 9. Experimental Activity

The most dominant activity of students at each meeting was the activity of conducting experiments with an average percentage value of $35 \%$. The activity of conducting experiments to collect data is most dominantly carried out by students because this activity requires a long time to obtain observations in the form of the upright standing of the balloon and the appearance of gas bubbles.

\section{Student Response}

The response questionnaire is an assessment of student worksheets that are distributed to them after the trial. The results of data processing can be observed in Table 5 . 
Table 5. Response Questionnaire Analysis Results

\begin{tabular}{|c|c|c|c|}
\hline No. & Rated aspect & $\mathbf{P}(\%)$ & Category \\
\hline 1. & $\begin{array}{l}\text { The student worksheet given by the teacher makes you } \\
\text { interested to learn it. }\end{array}$ & 97 & Very practical \\
\hline 2. & $\begin{array}{l}\text { The student worksheet provided by the teacher can help } \\
\text { you find concepts from the material being studied. }\end{array}$ & 97 & Very practical \\
\hline 3. & $\begin{array}{l}\text { You can identify problems based on everyday life } \\
\text { phenomena and laboratory phenomena in the student } \\
\text { worksheets. }\end{array}$ & 94 & Very practical \\
\hline 4. & $\begin{array}{l}\text { You can identify experimental variables about } \\
\text { phenomena in the student worksheet. }\end{array}$ & 97 & Very practical \\
\hline 5. & $\begin{array}{l}\text { You can formulate problems about phenomena in the } \\
\text { student worksheet. }\end{array}$ & 100 & Very practical \\
\hline 6. & $\begin{array}{l}\text { You can formulate hypotheses about phenomena in the } \\
\text { student worksheet. }\end{array}$ & 94 & Very practical \\
\hline 7. & You can understand the experimental procedures. & 100 & Very practical \\
\hline 8. & You can do a reaction rate experiment. & 97 & Very practical \\
\hline 9. & $\begin{array}{l}\text { You can write down the experimental data correctly } \\
\text { using the student worksheet. }\end{array}$ & 100 & Very practical \\
\hline 10 . & $\begin{array}{l}\text { You can analyze data from experiments that have been } \\
\text { carried out. }\end{array}$ & 100 & Very practical \\
\hline 11. & $\begin{array}{l}\text { You can write down the conclusions of the experiments } \\
\text { that have been carried out. }\end{array}$ & 100 & Very practical \\
\hline 12. & $\begin{array}{l}\text { You can reflect on problems and thought processes after } \\
\text { the learning activities are carried out. }\end{array}$ & 97 & Very practical \\
\hline 13. & $\begin{array}{l}\text { Student worksheets given by the teacher are arranged } \\
\text { systematically. }\end{array}$ & 100 & Very practical \\
\hline 14. & $\begin{array}{l}\text { The description or explanation in the student worksheet } \\
\text { given by the teacher is easy to understand. }\end{array}$ & 94 & Very practical \\
\hline 15. & $\begin{array}{l}\text { The student worksheet developed by the teacher is very } \\
\text { interesting. }\end{array}$ & 100 & Very practical \\
\hline 16. & Pictures or illustrations are clear and understandable. & 100 & Very practical \\
\hline 17. & $\begin{array}{l}\text { The instructions in the student worksheet help you } \\
\text { before carrying out learning activities. }\end{array}$ & 100 & Very practical \\
\hline
\end{tabular}

Based on Table 5. The developed student worksheepercentaged to be very practical because the precentage obtained $\geq 61 \%$ shows a positive response, and is supported by data from observations of student activities $\geq 61 \%$ of active students while using the student worksheet (Riduwan, 2015).

\section{Effectiveness}

The effectiveness of students' worksheets is described by an increase in the domain of knowledge and HOTS abilities of students.

\section{Domain of Knowledge}

The domain of knowledge test is carried out by doing 10 questions from indicators derived from the development of KD. 3.6 and 4.7. The results of students' knowledge domain pretest from the 33 samples used got an average value of 78.06. It is due to the low material knowledge of the reaction rate. However, after applying the student worksheet oriented to 
guided inquiry to students, the results of the posttest domain knowledge of students got an average score of 95.75 .

After obtaining the value of the knowledge domain, both pretest and posttest, then tested with a Paired Sample T-Test with SPSS to find out whether the value before the application of the student worksheet was different from after it was applied. The significance values obtained from the Paired Sample T-Test are listed in table 6 below.

Table 6. Paired Sample T-Test

\section{Paired Sample Test}

Sig. (2-tailed)

0.000

Based on Table 6. The Sig. (2-tailed) $<0.05$, so there is a significant difference between the knowledge domain of students before the student worksheet is applied and after the student worksheet is applied (Tarumasely, 2020). Meanwhile, to determine the increase in the realm of knowledge, the n-gain formula is used. The following is an illustration of the increase in the n-gain score of 33 students who took part in the trial.

The Domain of Knowledge N-Gain Score

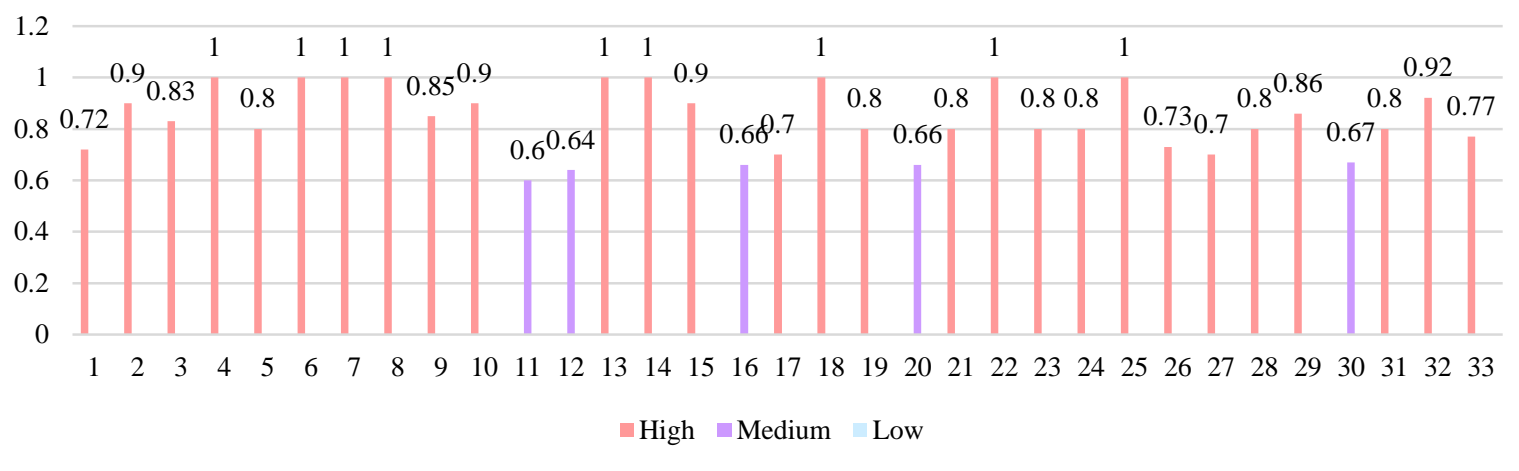

Figure 10. The domain of Knowledge N-Gain Score

Based on the results of the students' domain of knowledge, it was stated that the n-gain score on the high category $(\mathrm{g} \geq 0.7)$ was $84.84 \%$ and the medium category $(0.3 \leq \mathrm{g} \geq 0.7)$ was $15.16 \%$ of the students. This states that the developed student worksheets are very effective in increasing the students' knowledge domain.

\section{High Order Thinking Skills (HOTS)}

Students' HOTS abilities are trained at each meeting using student worksheets. The student worksheets contain the cognitive level C4, cognitive level C5, and cognitive level C6. The ability to analyze $\mathrm{C} 4$ including formulating problem formulations, determining experimental variables, and analyzing experimental data; the ability to evaluate $\mathrm{C} 5$ includes identifying problems, designing experimental procedures, and making conclusions; the ability to create C6 includes formulating hypotheses and creating ideas (Nurkholik \& Yonata, 2020).

The results of the HOTS pretest of students from 33 samples used obtained an average value of 71.78. It is because HOTS students have not been trained. However, after applying the Student Worksheet with guided inquiry to students, the students' HOTS posttest results got an average score of 94.84 .

After obtaining the value of the HOTS, both pretest and posttest, then tested with a Paired Sample T-Test with SPSS to find out whether the value before the application of the student worksheet was different from after it was applied. The significance values obtained from the Paired Sample T-Test are listed in table 7 below. 
Based on Table 7. The Sig. (2-tailed) $<0.05$, so there is a significant difference between the HOTS of students before the student worksheet is applied and after the student worksheet is applied (Tarumasely, 2020). Meanwhile, to determine the increase in HOTS, the $\mathrm{n}$-gain formula is used. The following is an illustration of the increase in the n-gain score of 33 students who took part in the trial.

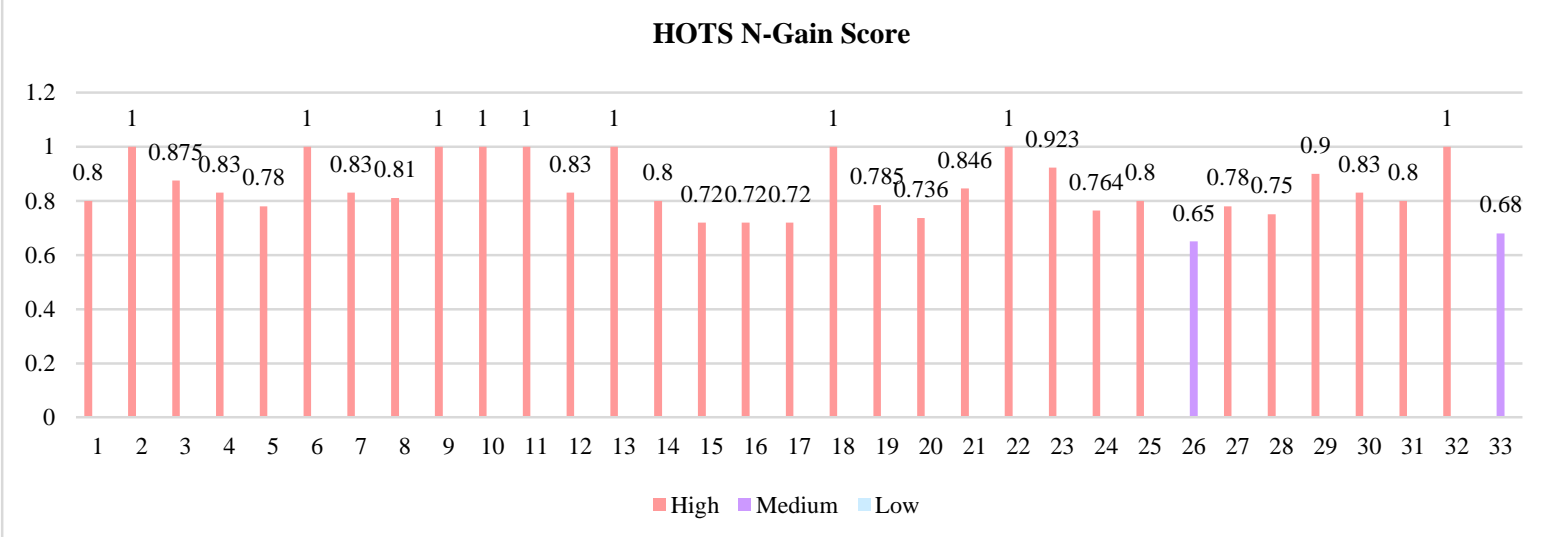

Figure 11. HOTS N-Gain Score

Based on the results of the students' HOTS ability, it was stated that the n-gain score on the high category $(\mathrm{g} \geq 0.7)$ was $93.93 \%$ and the medium category $(0.3 \leq \mathrm{g} \geq 0.7)$ was $6.07 \%$ of the students. This states that the developed student worksheets are very effective in increasing the students' HOTS. By Aditya's research (2020) that HOTS can be trained with guided inquiry-oriented student worksheets (Aditya \& Ismono, 2020). Due to the increase in students' HOTS, the 2013 curriculum objectives which require students to behave actively and analytically so that they can solve problems are achieved (Brookhart, 2010).

\section{CONCLUSION}

The validity of the student worksheets includes content validity of $93 \%$ and construct validity of $89.70 \%$ so that it can be declared very valid.

The practicality of student worksheets is obtained from positive responses with a percentage of $94 \%-100 \%$, so that it is stated to be very practical and supported by more relevant student activities than irrelevant activities.

The effectiveness in terms of the results of the knowledge domain test and HOTS with the Paired Sample T-Test each got a Sig. (2-tailed) value of 0.000 which indicates a difference in the average value between before and after the student worksheets are given, the results of students' n-gain on the knowledge domain test with high category of $84.84 \%$ and medium category of $15.16 \%$, and the results of students' n-gain on the HOTS test with high category of $93.93 \%$ and medium category of $6.07 \%$.

\section{RECOMMENDATION}

The developed student worksheets can be used for online learning, because there are experimental videos in the phenomena section. HOTS skills are further trained, especially for the C6 cognitive domain (creating), namely generating ideas and loading hypotheses for other cognitive level categories. Research using inquiry-oriented worksheets to train HOTS can be done on other chemical materials. 


\section{REFERENCES}

Abizar, H. (2017). Buku Master Lesson Study. Diva Press.

Aditya, K. F., \& Ismono. (2020). Development of Inquiry Student Worksheet to Train High Order Thinking Skill (HOTS) in Reaction Rate. Jurnal Pendidikan Dan Pembelajaran Kimia, 9(3), 107-114.

Andriani, D. W., \& Yonata, B. (2018). Melatihkan High Order Thinking Skills Peserta Didik Kelas XI SMA Negeri 12 Surabaya Melalui Implementasi Model Pembelajaran Inkuiri pada Materi Kesetimbangan Kimia. Unesa Journal of Chemical Education, 7(3), 333339.

Anjelicha, E. N., \& Ismono. (2020). Pengembangan LKPD Berorientasi Group Investigation untuk Melatihkan High Order Thinking Skills pada Materi Laju Reaksi. Unesa Journal of Chemical Education, 10(1), 28-37.

Arends, R. I. (2012). Learning to Teach Ninth Edition. The Mc Graw-Hill Companies Inc.

Arifin, Z. (2009). Evaluasi Pembelajaran. PT Rosada Karya.

Brookhart, S. M. (2010). How to Asses Higher Order Thinking Skills in Your Classroom. ASCD.

Cahyani, U. I., Nasrudin, H., \& Yonata, B. (2019). The Development of Students Worksheet Oriented Problem Solving to Train Creative Thinking Skills in Acid Base Matter for 11th Grade. UNESA Journal of Chemical Education, 8(2), 85-92.

Damaianti, O., Mawardi, M., \& Oktavia, B. (2019). Development of Guided Inquiry-Based Worksheets on Colloidal Material for Chemistry Learning Grade XI in Senior High School. International Jurnal of Progressive Sciences and Technologies (IJIPSAT), 14(13-19).

Firdausichuuriyah, C., \& Nasrudin, H. (2017). Keterlaksanaan Penerapan Model Pembelajaran Inkuiri Terbimbing untuk Meningkatkan Keterampilan Berpikir Kritis Siswa Materi Larutan Elektrolit dan Non Elektrolit Kelas X SMAN 4 Sidoarjo. UNESA Journal of Chemical Education, 6(2), 184-189.

Gustiani, S. (2019). Research and Development (R\&D) Method as a Model Design in Educational Research andiIts Alternatives. Holistics Journal, 11(2), 12-22.

Hake, R. R. (1998). Interactive-engagement Verus Traditional Methods: A Six ThousandStudent Survey of Mechanics Test Data for Introductory Physic Coures. Journal of Physic, 66(1), 64-74.

Imama, N., \& Nasrudin, H. (2015). Penerapan Model Pembelajaran Inkuiri untuk Melatihkan Keterampilan Berpikir Kritis Siswa Pada Materi Laju Reaksi di Kelas XI SMAN 1 Sreseh Sampang. UNESA Journal of Chemical Education, 4(2), 212-217.

Irham, S. M., Mr., M., \& Oktavia, B. (2017). The Development of Guided Inquiry-based Worksheet on Colligative Properties of Solution for Chemistry Learning. 1st International Conference of Mathematics and Science Education, 57, 38-42.

Julistiawati, R., \& Yonata, B. (2013). Keterampilan Berpikir Level C4, C5 \& C6 Revisi Taksonomi Bloom Siswa Kelas X-3 SMAN 1 Sumenep pada Penerapan Model Pembelajaran Inkuiri Pokok Bahasan Larutan Elektrolit dan Non Elektrolit. Unesa Journal of Chemical Educationof Chemical Education, 2(2), 57-62.

Khafida, I. L., \& Ismono. (2021). Pengembangan LKPD Inkuiri Berbasis Hands-On \& Minds-On Activity untuk Meningkatkan HOTS pada Materi Laju Reaksi. Unesa Journal of Chemical Education, 10(1), 38-47.

Khaleel Younis, B. (2017). The Effects of Scientific Inquiry Simulations on Students' Higher Order Thinking Skills of Chemical Reaction and Attitude towards Chemistry. American Journal of Educational Research, 5(11), 1158-1161.

Mulyana, S., Rusdi, \& Vivanti, D. (2018). The Effect of Guided Inquiry Learning Model and Scientific Performance on Student Learning Outcomes. Indonesian Journal of Science 
and Education, 2(1), 105-109.

Nurkholik, M., \& Yonata, B. (2020). Implementasi Model Pembelajaran Inkuiri untuk Melatihkan High Order Thinking Skills Peserta Didik pada Materi Laju Reaksi Kelas XI IPA MAN 2 Gresik. Unesa Journal of Chemical Education, 9(1), 158-164.

Permendikbud. (2013). Kerangka Dasardan Struktur Kurikulum Sekolah Menengah Atas/Madrasah Aliyah UU Nomor 69 Tahun 2013. Mendikbud.

Permendikbud. (2018). Kompetensi Inti dan Kompetensi Dasar Pelajaran pada Kurikulum 2013 UU Nomor 37 Tahun 2018. Kementerian Pendidikan dan Kebudayaan.

Purwanto. (2013). Evaluasi Hasil Belajar. Pustaka Pelajar.

Riduwan. (2015). Skala Pengukuran Variabel-Variabel Penelitian. Alfabeta.

Sugiyono. (2015). Metode Penelitian Kuantitatif, Kualitatif, dan R\&D. Alfabeta.

Suyono, \& Hariyanto. (2015). Implementasi Belajar dan Pembelajaran. PT. Remaja Rosdakarya.

Tarumasely, Y. (2020). Perbedaan Hasil Belajar Pemahaman Konsep Melalui Penerapan Strategi Pembelajaran Berbasis Self Regulated Learning. Jurnal Pendidikan Dan Kewirausahaan, 8(1), 54-65. 